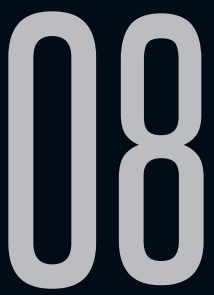

\title{
MURILO RUBIÃO CONTEMPORANEIDADE E CONCLAVES DA IMAGINAÇÃO: UM OLHAR PARA MARINA A INTANGÍVEL
}

Maria Zilda da Cunha (USP)

Recebido em 27 ago 2020. Aprovado em 18 out 2020.
Maria Zilda da Cunha é Professora da USP. Pósdoutora pela Universidade do Minho (2018) e pela Letras (2016), Doutora pela USP 2002). Líder do grupo de pesquisa: "Produções Literárias e Culturais para Crianças e Jovens". Vem publicando livros, capítulos de livros e artigos, bem como organizando número temáticos de revistas sobre a obra de Murilo Rubião, além de orientar pesquisas em torno da obra do autor. Lattes: http://lattes.cnpq.br/4302400907230914 ORCID iD: 0000-0003-0102-4445

Resumo: Murilo Rubião (1916-1991), representante do fantástico no Brasil, sempre enfatizou que muitos dos elementos de fabulação presentes na sua ficção provêm das leituras realizadas na infância e juventude - obras como A Bíblia, As mil e uma noites, contos de fadas, a mitologia grega, o Velho Testamento e o romance Dom Quixote, e a obra do mestre Machado de Assis, e de Poe figuram em seus testemunhos. De fato, é possível divisar, nos escritos murilianos, índices muito potentes de uma rica constelação de narrativas e de imagens que dessas reverberam. A análise de seu acervo concede-nos o perfil do autor mineiro como um guardião zeloso de memórias de si e de pessoas que com ele partilharam sentimento e 
ideias. A obsessiva reescrita do autor mineiro é uma marca importante de sua produção. Assim como o é a economia, a sintaxe sem ruídos, o apuro gramatical e a aproximação com o absurdo - aspectos que ocorrem em conformidade com uma narrativa fraturante - que nos leva a vislumbrar, pelas frestas de uma escritura impecável, a obscuridade, a fragmentalidade, as relações afectais e as profanações do nosso contemporâneo. Com vistas ao exame desses diálogos e à semiose criativa que preside tal processo, buscase perscrutar alguns eventos que sinalizam a tessitura ficcional do autor, pelo viés da Semiótica Peirceana e dos Estudos Comparados de Literatura, que nos facultam a correlação entre Literatura e outras artes, de certa forma, contemplada no curso deste artigo. Entre os 33 de seus contos publicados, selecionamos, aqui, para um olhar mais atento: Marina a Intangível. Palavras-chave: Murilo Rubião; Marina a Intangivel; Processos de criação; Profanação.

Abstract: Murilo Rubião (1916-1991), representative of the fantastic in Brazil, has always emphasized that many of the elements of fabulation present in his fiction come from the readings carried out in childhood and youth - works such as Bible, The thousand and one nights, fairy tales, mythology Greek, the Old Testament and the novel Don Quixote, and the work of the master Machado de Assis, Poe appear in his testimonies. In fact, it is possible to see, in murilian writings, very potent indices of a rich constellation of narratives and images that reverberate from them. The analysis of his collection gives us the profile of the Minas Gerais author as a zealous guardian of memories of himself and of people who shared feeling and ideas with him. The obsessive rewriting of the author is an important mark of his production. As is the case of economics, syntax without noise, grammatical accuracy and approximation with the absurd - aspects that occur in accordance with a 
fracturing narrative - that leads us to glimpse, through the cracks of an impeccable writing, the obscurity, the fragmentation, the affective relationships and the desecrations of our contemporary. With a view to examining these dialogues and the creative semiosis that presides over this process, we seek to examine some events that signal the author's fictional fabric, through the perspective of Peircean Semiotics and Comparative Literature Studies, which provide us with the correlation between Literature and others arts, in a way, contemplated in the course of this article. Among the 33 of his published stories, we have selected here for a closer look: Marina a Intangivel.

Keywords: Murilo Rubião; Marina a Intangível; Creation processes; Desecration.

\section{INTRODUÇÃO}

O ponto de partida para esta reflexão está inscrito no título que confiei a este artigo. Sobre Rubião (1916-1991), sabemos ser um cultor do fantástico que apresenta uma obra de apenas 33 narrativas publicadas. $O$ processo obsessivo de sua reescritura, seu apreço pelo universo do fantástico e a aproximação de seu estilo com o estranho, com o absurdo, bem como a economia, a sintaxe sem ruídos e uma redação com apuro gramatical e alta legibilidade caracterizam sua contística expressivamente focada pela crítica. Conheci Murilo Rubião. No ano de 1974, fui a ele apresentada por Nelly Novaes Coelho, quando estive, a convite da professora (para realizar um trabalho), na editora que ela dirigia - Quiron uma editora de pequeno porte de propriedade de seu marido. Nada sabia, na época, a respeito desse meu interlocutor. Lembro que me fez rir algumas vezes, o mineiro gostava de contar história com singular humor e ironia. Murilo fora à editora para entregar a 
Nelly o original de uma coletânea de contos - "O convidado" - para publicação. Ele relata que o conto que dá nome à coletânea teria levado 26 anos para ser concretizado em obra. Teriam germinado as primeiras ideias, em São Paulo, em janeiro de 1945, quando foi realizado o I Congresso Brasileiro de escritores. Um jantar de gala, em homenagem aos congressistas, foi oferecido, e teve lugar na casa de Lasar Segall. Teriam sido convidados Oswald de Andrade, Mario de Andrade, Caio Prado entre outros. Murilo comparece como chefe da delegação mineira. Tímido e totalmente perdido em meio ao tumulto da reunião, não conseguia acompanhar as conversas, não conhecia ninguém. Sentiu-se convidado por engano. Tentou escrever algo na mesma noite, mas não teve êxito. Essa experiência guardada na memória, e fruto de inúmeras (re) escrituras teria muitos anos depois se transformado no conto que ali estava sendo entregue para publicação.

Somente em 1989, trabalhando na Secretaria de Estado da Educação, e depois junto à missão do Banco Mundial, com atribuições de consultoria na compra de acervos de Literatura Infantil e Juvenil, é que volto a me encontrar, ali, pela via da produção impressa, com a instigante presença do autor mineiro.

Quanto à Nelly Novaes Coelho, a ensaísta e crítica literária nunca deixou arrefecer sua admiração e respeito pela genialidade do escritor. Murilo não esconde seu apreço pela estudiosa, questionado certa vez sobre a publicação de "O convidado", responde: "Capengando por aí, apesar dos esforços de Nelly Novaes Coelho", complementando: "Gosto muito de Nelly, por isso pedi que me pagasse os direitos autorais e livros. Aliás, devo a ela, junto com Eliane Zagury, os melhores artigos sobre minha reduzida 
obra". De resto, continuou ele, "Nelly sabe disso, sempre aceitei a literatura como uma maldição. Pouca satisfação me deu. Quando estou criando uma história sinto prazer. Depois é essa tremenda luta com a palavra, e revirar o texto, elaborar e reelaborar, ir para frente, voltar. Rasgar."

A expressão "conclaves da imaginação" alude ao compósito de imagens, ideias e vozes que se enovelam no perfazer das memórias murilianas, germinam sua criação e crítica, bem como outras que figuram guardadas e cuidadosamente referenciadas pelo autor mineiro. Convém lembrar que, com a organização e zelo que thes são peculiares, Murilo foi guardião da voz de Nelly (1922 - 2017). Voz de amiga, de crítica, de leitora contumaz da sua obra e dos autores pensadores que alimentavam a sua imaginação, sua técnica de narrar e o método criativo. A correspondência inédita de Nelly Novaes Coelho será em breve objeto de uma publicação.

O fato é que meu reencontro mais efetivo com Murilo Rubião aconteceu em 2016 - ano de seu centenário. Outros olhares, novas travessias e, para mim, novas descobertas. $\mathrm{O}$ trajeto para a realização de um trabalho de pós-doutoramento foi intenso e prazeroso. Este artigo é parte muito reduzida dessa aventura.

No que tange à contemporaneidade, convirá sinalizar nosso percurso convidando para nossa reflexão uma problemática posta por Blanchot (2018), em sua parte final de O livro por vir - "Para onde vai a literatura?" Nesta, o ensaísta francês, atento ao mundo atual, comenta a hipótese de que "a literatura se encaminha para o seu desaparecimento". De fato, essa é uma questão inquietante e provocadora, que, aliás, suscita a busca de algumas chaves para 
pensá-la. Talvez atraídos pelas análises de Blanchot e o olhar que este move para o segredo do devir, que subjaz ao "lance" de Mallarmé, ousamos apostar que, se concebermos a literatura como um fenômeno, essa arte seria impossível de ser perscrutada como algo totalmente presente e articulado; sua substância primordial não se dá senão em estado potencial, parcial, em ruínas, como arquétipo, enfim, como algo que não pode ser completamente alcançado, mas como signo para indiciar direções variadas a se examinar. Se o contexto contemporâneo reclama por reflexões novas em decorrência das profundas transformações a que vimos assistindo e vivenciando, e das problemáticas que disso emerge, inevitável será o fato de as textualidades, em que essa complexidade se engendra, não oferecer desafios. Na ficção atual, avatares aparecem replicando personagens híbridas pelo cruzamento de máquinas e organismos; o espaço faz-se no emaranhado de guerras, sons e imagens provenientes de diversas fontes de transmissão ambientando a diagramação e perspectivando modos insólitos de escrever a história e habitar o mundo. Por conseguinte, para leitura outras habilidades são requeridas.

Ora, se do sopro ancestral e da intensidade da claridade primeira pode se pensar que, no engendrar da linguagem, tudo poderia repousar em harmonia, diferentemente, houve um deslocamento em que a palavra estaria destinada a regressar ao início ou um "de outro modo", como diz Agamben, no livro A comunidade que vem, "depois de tudo estar definitivamente completo [...] algo como um frêmito do que é perfeito, uma irisação dos seus limites" (1993, p.72).

É na fissura que cifras disponibilizam-se aos poetas e prosadores, para que eles possam captá-las e, ao fim e ao cabo, 
reclamar de visões estanques para, na morada da estética, atravessar o limiar da ordem do verbo (que estava no princípio e se fez homem) para questionar a ordem e o discurso social que escamoteiam a complexidade da experiência humana. Descolando o verbo do sagrado, coloca-se, sob mira, sua profanação. Nestas sendas do contemporâneo, perspectivamos a literatura muriliana.

De fato, muitas dessas questões que estão a nos desafiar na contemporaneidade: a obscuridade desta era e suas consequências antropológicas, a fragmentalidade, as relações afectais, as crenças, as profanações, reverberam, de certa forma, numa narrativa fraturante, comparecendo em uma trama que se desdobra infinitamente pelos corredores do labirinto da obra de Murilo Rubião. O mundo que ele cria é regido pela magia, mas não oferece salvação ao homem, tampouco lhe dá conselhos, por outro lado, fá-lo viver a experiência mesma (muda) de sua condição de protagonista sem saída - única brecha de reflexão. O fantástico e o absurdo embaralham-se em acontecimentos de porte do real, tornando-se complicadores dos eventos que enredam as vidas dos personagens. O autor mineiro constrói, pela arquitetura de seu fantástico, insólitas veredas que comportam um emaranhado de questões de linguagem, de identidade, de tempo, de espaço, de duplo, do gozo do dizer, da palavra em que tudo está irreconhecível e oscilante, dúbio e contraditório.

Além do mais, a investigação muriliana acarinha as origens do seu fazer artístico, mas o faz atenta às emergências - daí sua obsessão pelo refazer - diríamos que sua investigação criativa se situa num limiar de indecibilidade entre sujeito e objeto, pois nela a emergência dos fenômenos coincide com a emergência do sujeito cognoscente. 
Convidando-nos a profanar, Agamben (2018) alerta para o fato de termos perdido as artes de viver - que é a da infância - lugar primeiro da mais séria profanação da vida. Esta reflexão do filosofo italiano, abre-nos uma face da discussão sobre o fantástico de Murilo Rubião, o inaugurador do "insólito absurdo", que, em 1974, teve $O$ pirotécnico Zacarias transformado em best seller.

$\mathrm{Na}$ contramão das teses derivadas de toda a pesquisa e do conjunto de ideias que vimos defendendo, seja na docência, na secretaria de educação, na missão do banco mundial (assessorando a compra de acervos para a escola), seja na universidade, comparecem algumas hipóteses. Entre essas a de que Murilo Rubião teria ocupado

o universo dos "escritores menores", porque a sua obra era apontada como literatura infantojuvenil - muitas vezes, associada à literatura (para) didática -, ou como representante do fantástico - literatura de divertimento, descompromissada -, duas vertentes que correspondem ao que a crítica reconhece - e hoje estuda - como "literatura menor" (GARCIA, 2016, p.31).

Dois pontos que, evidentemente, levam a uma severa indagação - sobre o ser menor da literatura infantil e juvenil - (em função de seu leitor? Do seu autor? Do endereçamento?) e o fato de se entender o fantástico como literatura descompromissada. Esta última, vale ressaltar, discutida com força intelectual e severa competência pelas investigações e publicações realizadas pelo Grupo de Pesquisa Nós do Insólito: vertentes da ficção, da teoria e da crítica (UERJ/CNPQ). Seriedade e competência que nos levaram, bem como ao nosso grupo de pesquisa ${ }^{1}$, a participar dos diversos 1 Grupo de pesquisa Produções Literárias e Culturais para Crianças e Jovens (CNPQ/ USP) de que sou líder. 
eventos que organizam, assim como balizaram a escolha de meu supervisor Prof. Dr. Flavio Garcia².

A problemática referenciada mobilizou-nos a agenciar nossa investigação sobre o fantástico, seus arredores e a obra muriliana. Constituiu essa, também, a motivação para o recorte do corpus. Além de diagramar o caminho da metodologia no exame de seu processo de criação: complexo caminhar em direção de uma meta - processo de causação final, na concepção da semiótica peirceana, como demonstrado por Cecília Salles (1992). Uma semiose que engendra um jogo temporal em que o futuro interpreta o passado e o ato comunicativo se inscreve no perfazer da escritura - Murilo como leitor de si mesmo.

Se a prosa muriliana tem conformação com aspectos da infância, é com Agamben (2014) que se traz essa discussão. Para o autor italiano, importa perscrutar o espaço do balbuciar da infância da linguagem ou morada infantil em que se formam os sons primeiros da língua materna entre experiência e linguagem, nas suas palavras: "A infância, como o lugar da experiência muda, o que já implica colocar a questão sobre a relação experiência e linguagem. O elemento que poderia fazer a conexão entre esses dois termos seria a infância" (2014, p.107).

Na esteira de Agamben, se esse é o lugar topológico que desvela um olhar originário, é o que pode ser compreendido como o espaço do lugar estético - para brincar ou jogar - abrindo-

2 Prof. Dr. Associado da UERJ. Coordenador da UDT LABSEM; Coordenador do SePEL. UERJ; Coordenador do NEF.UERJ; Co-coordenador do Dialogarts Publicações; Editor do DDIF Editor do Caderno Seminal; Líder do GP (CNPq) "Nós_do_Insólito: vertentes da ficção, da teoria e da crítica". Membro Fundador do GT (ANPOLL) "Vertentes do Insólito Ficcional". 
se para oferecer ao fantástico a dimensão ficcional do ser na voz da negatividade da linguagem, em sua potência de ser e não ser, da linguagem enquanto um querer-dizer. Desse modo, pode-se inferir, por deixar o vazio da sugestão do fantástico significarse sob a caracterização de similaridade (do "como se" e "como se vê") na ambivalência do olhar ficcional e na diferença entre língua e discurso, uma fratura é provocada na qual emerge uma estética. Nossa hipótese é a de que soube Murilo perscrutar, em tal lugar, a gestação da potência criativa do insólito do fantástico e cumprir a seu modo uma profanação. Ressalte-se profanar, aqui, não significa simplesmente abolir e cancelar as separações, mas aprender a fazer delas um uso novo, a brincar com elas.

\section{TRADUÇÃO, METAMORFOSE, MOVIMENTO CRIADOR E AMOR EVOLUTIVO: A ÉTICA E A ESTÉTICA MURILIANA}

É fato que a estética do movimento criador implica repetição, remarcação e metamorfose, e engendra uma cadeia infinita de ideias em série de aproximações para atingir a concreção de uma obra. Essa é marca precípua do processo criativo de Murilo Rubião "A obra em si surge de algum lugar do inconsciente ou do passado. De onde exatamente o escritor não sabe. Mas tem algo do momento, do que ocorre no cotidiano da gente."3

As palavras do escritor mineiro atestam ser o artista sabedor de sua sina, a de se tornar um tradutor de suas interpretações, das interpretações que ele faz do mundo, dos signos que se desdobram e entram na cadeia da criação. Desse modo, a criação

3 Murilo Rubião, Arte Quintal - Conversa de botequim. Acervo dos Escritores Mineiros (AEM) da Universidade Federal de Minas Gerais, consulta realizada durante a pesquisa de pós-doutorado realizada sob a supervisão do Prof. Dr. Flavio Garcia Acesso em 2016. 
é observada no estado de contínua tradução, em que regressões e progressões são inegáveis - uma perpétua metamorfose. Um jogo complexo de interpretantes a franquear aproximações entre leitura, releitura e tradução. Até porque, tradução, na perspectiva benjaminiana, "é um modo, por assim dizer de medir a estranheza das línguas entre si" (BENJAMIN, 2013, p.110), dado que "é a palavra e não a frase, o elemento originário do tradutor" (p.62), bem como o intenso esforço de "provocar o amadurecimento, na tradução, das sementes da pura linguagem, parece inalcançável" (2013, p.111). Sob esta consideração depreende-se o grau de complexidade do sistema semiótico que engendra o pensamento tradutor, ao abrigar "as sementes da pura linguagem", de sensações, percepções, signos que germinam as linguagens sonoras, imagéticas, verbais - intercambiando forças, dinamizando novas formas lógicas de raciocínio, de sintaxes, balizando escolhas para a linguagem manifesta - aquela que se concretizará na obra.

Walter Benjamin assinala ainda que "não seria possível tradução alguma se ela pretendesse, em sua essência última, assemelhar-se ao original. "Pois em sua pervivência, que não mereceria tal nome não fosse metamorfose e renovação". (2013, p.108).

A obra vai se construindo nesse movimento de renovação e metamorfose - a cada escrita - um movimento de tradução que se repete em novas traduções.

Tania Carvalhal (1993), perspectivando esse esforço criativo, refere-se ao ato de traduzir como o de recriar, isto é, uma operação que transporta as intenções primeiras e as faz ressurgir com vitalidade. 
Incontestavelmente, Rubião, em seus empreendimentos narrativos, retraça, em tradução, novos fios de outros textos, compondo estratos intertextuais à luz de estruturas prodigiosas.

No ensaio "A tarefa do tradutor", a que vimos nos aludindo, Walter Benjamin expõe reflexão sobre sua própria experiência como tradutor dos poemas de Baudelaire. Parte da tradução interlínguas, considerando o processo ocorrido na tradução de poemas, e assim constrói uma teoria da tradução aplicável a diferentes produções e sistemas semióticos. Suas considerações trazem propostas relevantes. O que "diz" uma obra poética? O que comunica? Muito pouco para quem a compreende. O que lhe é essencial não é comunicação, não é enunciado. E, no entanto, a tradução que pretendesse transmitir algo não poderia transmitir nada que não fosse comunicação, portanto, algo de inessencial. Pois essa é mesmo uma característica distintiva das más traduções. Mas aquilo que está numa obra literária, para além do que é comunicado - e mesmo o mau tradutor admite que isso é o essencial - não será isso aquilo que se reconhece em geral como o inapreensível, o misterioso, "o poético"? Aquilo que o tradutor só pode restituir ao tornar-se, ele mesmo, um poeta? (2013, p.102).

A traduzibilidade subjacente ao "original" permite à tradução estabelecer com este uma "íntima conexão" (BENJAMIN, 2013, p.104); ao mesmo tempo que dele se distancia, exatamente, por se tornar autônoma. Para o ensaísta: "[...] graças à traduzibilidade do original, a tradução se encontra com ele em íntima conexão. Essa conexão é tanto mais íntima quanto para o próprio original ela nada mais significa" (2013, p.104) O processo criativo implica, portanto, essa traduzibilidade, movência, metamorfose. Complexo 
movimento de criação em que o autor se cria ao longo da consecução da obra, lembrando Bakthin (2010). O amálgama entre o criador, a criação e a criatura torna-se tão intenso que Rubião chega a afirmar: "todo escritor depois de certa época vive plenamente a literatura que faz. A ponto de não saber se está sendo influenciado pelo que escreve ou se está fazendo um tipo de literatura de acordo com sua tradição, com o meio em que ele vive". 4

Para Cecília Salles (2009, p.28) o gesto criador constitui um movimento com tendência. A tendência não constitui a solução concreta, mas implica certa vagueza. Atesta Rubião: "a obra em si surge de algum lugar do inconsciente ou do passado. De onde exatamente o escritor não sabe". Um movimento dialético A dinâmica do processo, por sua vez, é a explicação dessa vagueza. Murilo comenta: "Eu vou me empolgando com o conto, mas depois, completamente frio, devo verificar o que é somente emoção e separar do que pode figurar na história"5.

O percurso criador implica essa trajetória orientada por um objetivo a atingir, "um mistério a penetrar", de acordo com Picasso (1985). Se a intenção do artista é dispor a obra no mundo, vale considerar que seu desejo nunca é alcançado totalmente, posto que ele se renova na criação de cada obra. Por isso, Calvino (1990) diz que prefere escrever a falar, pois escrevendo pode emendar cada frase quantas vezes achar necessário. Murilo comenta que costuma trabalhar demoradamente, "anoto o eixo e vou

4 Em entrevista cedida a Elizabeth Lowe 40/50. Acervo de Escritores Mineiros. Consulta em 2016.

5 Entrevista cedida a Paulo Thielmann. Jornal Estado de Minas. 24.Out.1986. Acervo de Escritores Mineiros. Consulta em 2016. 
lapidando vagarosamente. Elaboro e reelaboro os meus contos até à exaustão, numa busca desesperada de alcançar a clareza, as palavras exatas". ${ }^{6}$

Esse processar é gerido por propósito, por uma meta a ser alcançada - é o movimento de um processo télico que vai engendrando o criador em uma busca pela verdade que a obra acabada Ihe dará. (SALLES, 1992, p.75). No entanto, ressalte-se, uma verdade equalizada com a arte - "uma verdade revestida de formas", diz Lasar Segall (1984). Algo passageiro e determinado por escolhas estéticas. A verdade da obra de arte, determinada pela estética, é algo que vai brotando de sua própria textura - de sua própria linguagem, em razão do empenho do criador em produzir a qualidade de sentimento que provoca a beleza - no sentido borgeano. Algo muito bem definido por Edgar Alan Poe, no prefácio que faz para seu livro Eureka:

Aos poucos que me amam aos quais eu amo; aos que me sentem, mais do que me pensam; aos sonhadores e aqueles que confiam nos sonhos como as únicas realidades, dedico este livro de verdades, não como Propagador de verdades, mas pela Beleza que de sua verdade brota, tornando-o verdadeiro. (1986, p.19)

Essa busca pela verdade é compreendida por Ransdell (1977), como o encalço a uma posse da revelação da realidade; tratase de uma tendência para a verdade, uma tendência à aquisição de competência, encontrada na vida em geral, nos humanos, revelada como tendência para aprender - uma competência

6 Entrevista cedida a Paulo Thielmann. Jornal Estado de Minas. 24.Out.1986. Acervo de Escritores Mineiros. Consulta em 2016. 
comportamental. Recorrendo a Peirce, ${ }^{7}$ entendemos a relação desta com a verdade. Para esse pensador, o que faz a "verdade" verdade é exato essa competência comportamental, mesmo que o motivo real da busca possa ser o sentimento de satisfação que a acompanha.

No caso de Murilo Rubião, é notável uma ação compulsiva e obsessiva que dinamiza essa busca pela verdade. "Quando estou criando uma história sinto prazer. Depois é essa tremenda luta com a palavra, e revirar o texto, elaborar e reelaborar, ir para frente, voltar". Em entrevista, afirma o autor mineiro: "escrevo e reescrevo com grande tenacidade. Insatisfeito com a literatura que faço". ${ }^{8}$ Mostra-se-lhe incansável a busca pela construção que exprima inteligibilidade verbal a enredos convidativamente sinistros. A respeito da intencionalidade desse processo, diz: "busco a palavra simples a linguagem intemporal". E a "estrutura de meus contos segue uma lógica inflexível, mesmo falando de uma coisa ilógica". 9

A propósito de seu fazer, diz Rubião: "infelizmente, escrever para mim é a pior das torturas". Portanto, para o autor de 0 Edifício, sua construção se dá num campo de insatisfação, ele próprio confessa: "o ofício de escrever torna-se demasiadamente penoso" ${ }^{10}$. O estigma da insatisfação que perpassa a produção da obra muriliana remete-nos às palavras de Vargas Llosa, quando diz que "ninguém que esteja satisfeito é capaz de escrever, ninguém que esteja de acordo, reconciliado com a realidade, cometeria o ambicioso desatino de inventar realidades verbais". (1985, p.136).

7 Collect Papers 8 vols USA Havard Press.

8 Murilo Rubião, In: O Pirotécnco Zacarias, 1974, p.4.

9 Murilo Rubião, In: O Pirotécnco Zacarias, 1974, p.4.

10 Murilo Rubião - Folha de Minas. 20.Out.1940. Acervo de Escritores Mineiros. Acesso 2016. 
A repetição, a remarcação e a metamorfose sinalizam a irrefreável condição do escritor em face do que não o faz se reconciliar com a realidade (com que se depara). A montagem singular de estratos intertextuais à luz de estruturas prodigiosas, sua pirotecnia escritural em novos arranjos sugerem a procura de "novas formas de vontade de verdade" (FOUCAULT, 1996, p.16).

A obstinação muriliana, no duplo encalço: o da posse da revelação da realidade e o da verdade que brota da textura de sua obra, promove singular exercício de "competência comportamental". Confiando à construção de uma lógica alicerçada esteticamente, o criador revela sua prática refletida de liberdade - ou a ética de ser escritor. Deveras atento ao contexto histórico e social, como se depreende de seus depoimentos, de sua história de vida, mostra, por seu lado, não se submeter às formas de subjetivação a que estamos conformados, aos modos de sentir sentidos já postos. Testemunha: "A presença do fantástico é capital em minha obra." E "o que está por trás da realidade, o que não fica muito visível para nós, o fantástico redescobre para nós." 11

Incontestavelmente, projeto estético e ideológico engendramse. No lusco-fusco da ilogicidade, se redesenham modos de se olhar pelas frestas da realidade estabelecida, seguramente, esse escritor fissura a camada lógica do verbal.

Não à toa foi incansável na busca de clareza, de inteligibilidade e de construção de enredos sinistros. O fantástico foi exigindo do contista mineiro, dessa forma, uma ordem no que se refere à exposição dos dados que encadeiam acontecimentos de alta 11 Murilo Rubião - Supl. Lit.n. 959 /1985. Acervo de Escritores Mineiros. Acesso 2016. 
gramatura ilógica. Estratégia que dinamiza um jogo de dispositivos narrativos que se emaranham e se alternam à exaustão, tramando uma tessitura na qual implodem conflitos de escopo predominantemente insólitos. A reescrita infatigável de Murilo, nessa ordem de ideias, persegue o mal-entendido, a confusão que, por si, ofusca. É o que demonstrou Ricardo lannace (2017) nas leituras analíticas que realizou de textos como "O Edifício" e "A diáspora", assinalando como esses aspectos estão dentro da tessitura revelando a complexidade da literatura e do diálogo que estabelece com outras linguagens.

Notadamente, desafios se impõem para a consecução de uma obra rara e densa como a rubiana, "de um insólito despreocupado que suprime qualquer farol e nos faz sentir como se as leis do mundo estivessem normalmente refeitas. Uma naturalidade admirável, feita de supernaturalidade"12.

Rubião, certa vez, comenta, com sua singular ironia, que "os escritores novos sentem fascínio pela literatura, mas quando é preciso trabalhar mesmo, o escritor novo decide ser advogado etc..."13 Para o autor, fazer literatura demanda muito esforço e muita persistência “O convidado' foi um texto que levei 26 anos para concluir"

Em depoimento o escritor mineiro confere ao trabalho do ficcionista algumas caraterísticas:

É normal o fato de o personagem fazer uma série de coisas que o autor não deseja. Ou então é a própria

12 Carta de Antonio Candido dirigida a Murilo Rubião, encontra-se, entre outras correspondências, no Acervo dos Escritores Mineiros. Consulta realizada em 2016.

13 Entrevista concedida a Jorge Fernando dos Santos. Acervo dos escritores mineiros. Acesso em 2016. 
história que passa a se conduzir sozinha. Mas em literatura o que realmente importa é o trabalho que se tem e não a ideia inicial. Então, tem esse processo de reelaborar e nesse processo a gente percebe uma série de fraturas no texto e mesmo alguns erros. ${ }^{14}$

Autor que mais reescreveu, que inventou novas história, Murilo fala da força do processo criativo que imanta a sua criatura - a obra em que os personagens parecem ganhar autonomia; fala do processo criador como trabalho que exige o reelaborar constante, fala da fratura - ou do lugar vazio que o autor mesmo cria e que o faz voltar infatigavelmente para examinar. Esse lugar fraturado e ilegível é o que torna possível de leituras cada vez mais vigilantes.

Sendo as minhas histórias desde os primeiros rascunhos muito grandes, aumentadas constantemente com novas anotações que vão surgindo, o meu trabalho é reduzir esse material ao mínimo. No escrever e reescrever eu consigo dar certa solidez à estrutura. Em seguida, a redação final que nunca é final, ainda mudo bastante a espinha dorsal do conto. O núcleo central fica, mas a história fica totalmente modificada. Minha tarefa cortar palavras resumir parágrafos. Mexendo e remexendo, mas a história é a mesma. Engano pensar que a história muda, de quem não conhece o método de trabalho. ${ }^{15}$

Murilo comenta sua atenção constante ao trabalho que realiza, deixa entrever a vigilância de que necessita para ajustar a autonomia dessas criaturas que urde, de atitudes imprevisíveis - frutos da

14 Entrevista concedida a Jorge Fernando dos Santos. Acervo dos escritores mineiros. Acesso em 2016.

15 Murilo Rubião - Entrevista concedida a Leonor Basséres e Maria Cecília de Almeida - Jornal de Debates 5- 11.Abr.1976. Acervo de Escritores Mineiros. Acesso 2016. 
imaginação que ganham mobilidade para além do previsto pelo autor que, como seu primeiro leitor, é surpreendido por sua própria criação. Confessa que é reescrevendo reiteradamente que consegue dar solidez ao texto. Também relata que suas histórias começam grandes e, nesse sentido, demandam um esforço presidido por raciocínio de economia, capaz de ir esquematizando, e deixando as histórias mais compactas. Para enfim, reduzir o material ao mínimo.

Ao referir-se ao principal desafio que enfrenta em face da edificação do seu projeto de fantástico, Murilo diz:

a dificuldade que o escritor tem de impor uma possível realidade como sendo realidade, o suprareal dado em ternos claros e normais. Como se a convivência com seus dragões, seus monstros, tivesse a maior naturalidade. Então o escritor tem primeiro que conviver com o mistério. Depois de certa convivência, ele passa a tratar o suprareal como se fosse realidade. Se ele cai na fantasia, no fantástico gratuito, ele não consegue impor o seu mistério. ${ }^{16}$

Para o autor de "O Pirotécnico Zacarias", o fantástico contemporâneo demanda "a necessidade de o escritor impor a sua irrealidade como se fosse real, a ponto de o leitor, terminando a leitura, ficar numa certa dúvida se a realidade em que vive não será falsa, e se a realidade verdadeira não será aquela da ficção" ${ }^{17}$.

O zelo extremado para com a linguagem não só perfaz uma redação impecável, como propicia a esse escritor uma dupla experiência: no contato efetivo com a realidade, visualizar 16 Murilo Rubião - Entrevista concedida a Elizabeth Lowe. Acervo de Escritores Mineiros. Acesso 2016.

17 Murilo Rubião - Entrevista concedida a Elizabeth Lowe. Acervo de Escritores Mineiros. Acesso 2016. 
cifras que nela se escondem, possibilidades que ela mascara; e recolher do ventre da arte aquilo que está ainda invisível, tangenciar o inapreensível.

Estas reflexões nos remetem ao fazer poético sinalizado por Agamben como o "Iugar mediador' que era próprio do espírito" (2007, p.209). Por meio da linguagem, os poetas provençais procuram, assim, sobrepor-se à fratura metafísica entre visível e invisível, ligar a matéria à alma e, em último caso, realizar o amor. É o desejo por um objeto inapreensível que anima o amor pela imagem deste objeto (ou por seu fantasma), ao qual o poeta se remete nas inesgotáveis e sempre vãs tentativas de retê-lo. A palavra poética, diz Agamben:

Viria assim a estabelecer-se como o lugar no qual a fratura entre o desejo e o seu inapreensível objeto - que a psicologia medieval, com profunda intuição, havia expresso identificando Eros com o jovem que tanto amou sua sombra, que morreu - encontra sua conciliação, enquanto a mortal doença heroica, na qual o amor assumia a máscara saturnina do delírio melancólico, celebra seu resgate e o seu enobrecimento. (2007, p.212)

Em regiões da palavra muriliana incrustam-se esses fantasmas - do inapreensível, do inexplicável. À guisa de exemplo, recordese do texto muriliano "A flor de vidro" publicado no ano de 1965 no livro Os Dragões e Outros Contos: "Da flor de vidro restava somente uma reminiscência amarga" - A imagem é rememorada por movimentos do corpo; por onomatopeias do trem de ferro; pelos campos verdes e cinzentos; sorriso e não-sorriso; paredes alvas do casarão; exterior x interior; doce e amargo. Essas metonímias conformam metamorfoses visuais fantasmáticas - flor 
de vidro > flor azul > lenço branco. Nos reiterados chamamentos: "Marialice, Marialice, Marialice", a sonoridade e o rítmo engendram o canto poético, como cantos rituais. Perfaz-se em visão onírica em encontro de coincidência e não coincidência por meio da repetição li/li/li. Os lugares da saudade, do pathos amoroso - são marcados por ausência, lugares incertos, sujeito e objeto indistintos; no limiar de trevas e luz entre lembranças e esquecimentos / sonho. Restos esquecidos e relembrados pela memória do corpo (na voz). O espectro fantasmático figura-se em combinação de sujeito e objeto pelo efeito pretendido do uno.

São sondagens importantes, elas regem semioses criativas próprias do pensamento e do fazer poético. Movimento de sondagem, de repetição, remarcação e metamorfose que caracteriza o crescimento e o desenvolvimento de uma ideia. A mente, nesta perspectiva, opera seduzida por essa ideia. Uma evolução e crescimento marcados por uma tendencialidade. Na concepção da semiótica peirceana, trata-se de um pensamento e de uma ação operativa regidos pela lei do amor - um amor evolutivo. Notadamente, esse amor rege a escritura muriliana.

Peirce, para explicar essa forma de crescimento do pensamento - o pensamento que vem do amor, que vem do impulso ardente de satisfazer o maior impulso do outro, parte do evangelho de São João, e assim explica o amor evolutivo:

Suponha, por exemplo, que eu tenha uma ideia que me interesse, é minha criação. É minha criatura. Eu a amo e vou me dedicar a aperfeiçoá-la. Não é tratando com meu círculo de ideias com justiça fria que as farei crescer, mas agradando-as e acariciando-as como faria com flores do meu jardim. $(1955$, p.363) 
O filósofo continua dizendo que: "o movimento do amor é circular: no mesmo impulso dá independência para suas criações, e as ata em harmonia". Ao relacionar o conceito de amor desenvolvido por Pierce ao de Platão. Savan ${ }^{18}$ comenta que para ambos os pensadores amor é o que nos move a fazer associações políticas, buscar justiça, sabedoria, conhecimento e beleza. Amor é sentimento lógico - central para a filosofia, para a ciência, para a arte, para a sociedade.

Evidentemente, há permanentes intervenções, imprevistos e lutas à criação desenvolvendo, de algum modo, o do pensamento do escritor. Como diz Rubião, "A Literatura requer muito trabalho."19 Contudo, acarinhar a obra também é parte do processo do escritor mineiro: "costumo trabalhar demoradamente, anoto o eixo e vou lapidando vagarosamente." A relação com a literatura para ele tem conexão com a vida e o mundo: ${ }^{20 " S e m p r e ~ v i ~ o ~ m u n d o ~ l i t e r a r i a m e n t e . " ~}$ Sempre vi o mundo literariamente." O escritor não separa a vida da literatura, "vida e literatura são uma coisa só."21

O que está numa obra literária, seguramente, vai muito além do que é comunicado. Na esteira de Walter Benjamin, poderá ser exatamente isso o que se reconhece, em geral, como o inapreensível, o misterioso, "o poético". Aquilo que o artista só pode restituir na experiência mesma da linguagem, se ele se tornar, ele próprio, um poeta. (BENJAMIN, 2011, p.102).

18 Em Comunicação intitulada: Peirce's semiotic of emotion, durante o Congresso Internacional de Semiótica, em 23.Out.1981.

19 Murilo Rubião: Entrevista cedida a Giselle Dupin e Francisco de Morais Mendes. Disponível no Acervo de Escritores Mineiros, acesso em 2016.

20 Murilo Rubião em entrevista cedida a Carolina Marinho, intitulada Do ex-mágico ao Girassol Vermelho. s/d disponível no acervo de Escritores Mineiros. Acesso em 2016.

21 Jornal Tribuna de Minas Gerais, junho de 1988. Acervo de Escritores Mineiros. Acesso em 2016. 
Segundo Fayga Ostrower, o poeta ou o artista, em geral, especula sobre formas e ordenações, sendo que "as decisões que perfazem o processo criador não pertencem ao âmbito da imaginação: só podem surgir através do fazer concreto, como opções diante dos fatos reais." (1995, p.21). No entanto, "só se cria dentro da especificidade de uma determinada matéria e só com o pleno domínio de sua linguagem." (1995, p.223). O realizado será sempre diferente da intenção. Os diálogos do artista com a matéria são diálogos íntimos consigo mesmo.

\section{METAMORFOSES EM REVERSÃO /CONVERSÃO NA DIREÇÃO DAS QUALIDADES}

A título de reflexão e apreciação crítica, selecionamos algumas obras que podem nos trazer pistas expressivas para as reflexões aqui pretendidas.

A primeira remete à figura do touro pertencente à $2^{\text {a }}$ fase do conjunto de estudos que Picasso realiza para a consecução de sua obra Guernica.

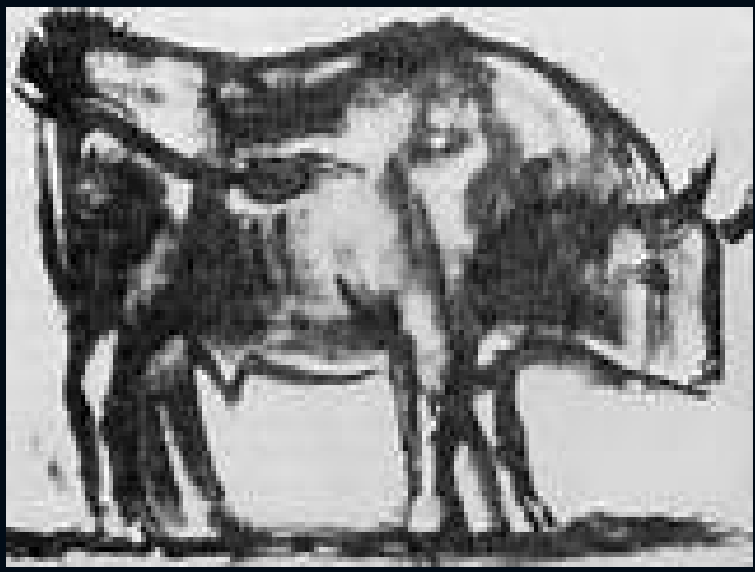

Figura 1. A figura do touro. ${ }^{22}$

22 Pablo Picasso (1945). El Toro, Painel I. 
A segunda consta do conjunto de imagens de Picasso que mostram a metamorfose de um touro, os esboços para Guernica.

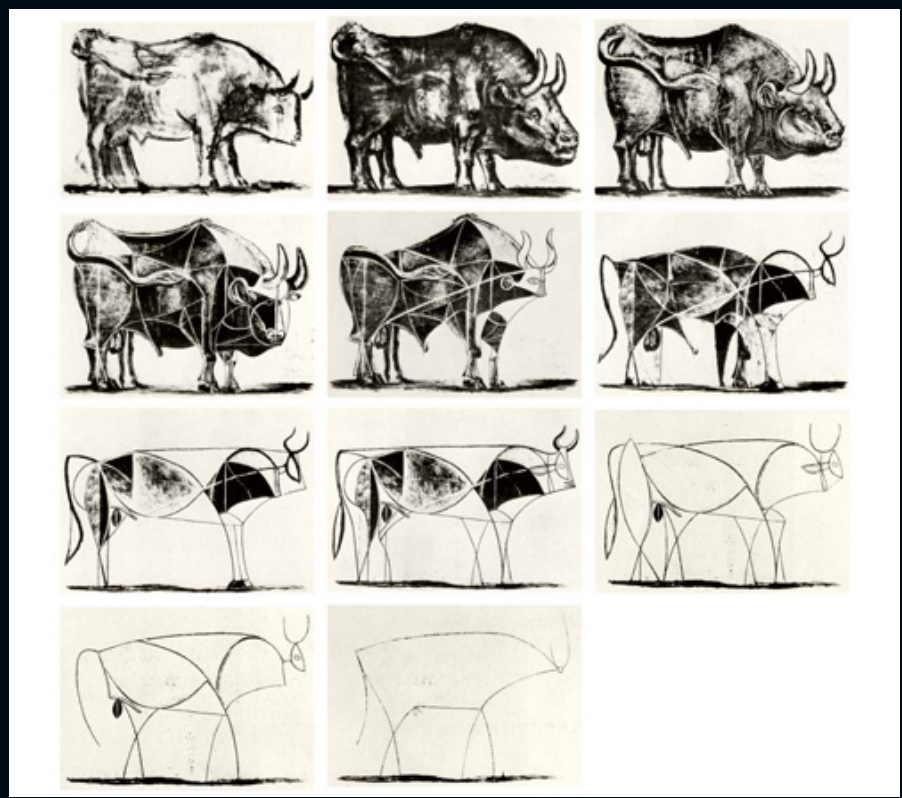

Figura 2. Picasso metamorfose de um touro ${ }^{23}$

O esforço se faz para alcançar a qualidade espectral de um touro, atingindo uma espécie de imagem quase sem figuração, como se o artista quisesse atingir a alma do animal. A imagem, aos poucos, vai corroendo a lógica da contiguidade à procura da analogia, em processo degenerativo, o signo touro se firma em qualidade. Traço a traço, vai se processando uma metamorfose. Como se o artista tivesse que ir des /fazendo, des/ crevendo, re/ escrevendo para reimaginar. Cada etapa é uma revelação, um lance a ser percebido, um novo signo vai se instaurando. Observa-se, na última fase dos esboços picassianos, uma subversão lógica - do padrão simbólico do signo para a configuração icônica - ocorre.

23 Pablo Picasso (1945). El Toro, Série de 11 litografias. Estudo para Guernica. 
A terceira imagem refere-se à tela de Miró (fig. 3) Azul III, em que é tal a evidência de ser atingida a qualidade do signo, que a cor é simples cor (ícone de si mesma). No dizer de Argan, nesse trabalho "não se procura significado ulterior para além da percepção. É como se "a profundidade do inconsciente se resolvesse totalmente na superfície da imagem visual". (1993, p.458). Complementando, diz o crítico de arte italiano que: "A motivação não é causa a que corresponda logicamente um efeito, é um impulso que se transmite e perdura no gesto que forma a imagem, pode-se lê-la na vibração das linhas e na fosforescência das cores, como uma corrente elétrica que torna incandescente o circuito que percorre" (1993, p.459). A cor reduz-se ao apelo sensorial.

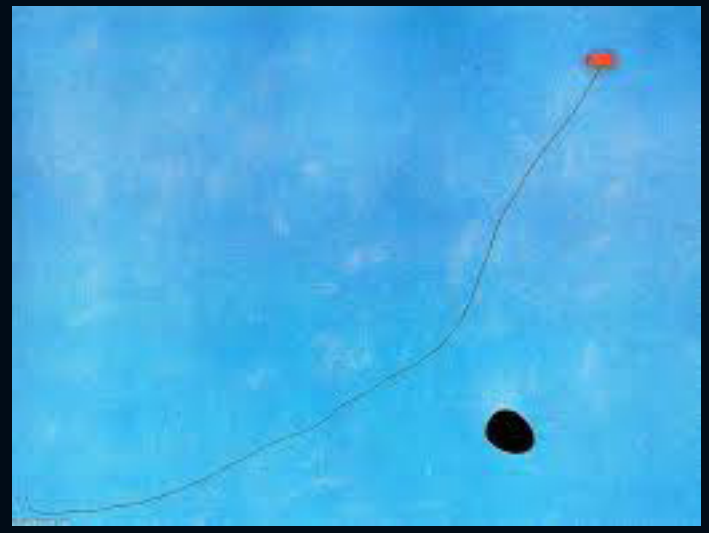

Figura 3. Joan Miró - 24

A propósito, a que se destina essa cor a não ser apresentar-se a si mesma? Um signo icônico que se mostra sem esperar definição. A cor, como arte, se mostrando. Nessa tela, o que temos diante de nós é azul matizado, qualidade reduzida a si mesma. Vibrando, em disponibilidade, sinestesia. A tela fala de cores, fala da própria 
pintura. Os tons de azul, manchas amarelas e preto iconizam possibilidades interpretantes, potencializam ambiguidades, sugerem devaneios. No azul insolente, elétrico, por si só faz a tela vibrar, há sugestões apenas - talvez de mistérios insondáveis ou da imensidão do universo. Apenas possibilidades entre outras. Um sentimento espacial que flui do centro da tela. É um espaço à espera da criação.

A pintura, em sua historicidade, nem sempre se fez não representativa, na verdade, ela antecedeu, e dividiu funções com a fotografia, dado o caráter representativo e de conexão direta com o referente que atingiu, dada a possibilidade de dar ao objeto o seu duplo. Ela cumpriu a função de representar simbolicamente aspectos culturais e relações de poder.

Esse processo de reversão /conversão, na direção das qualidades por meio de uma vampirização sígnica, nutre o artista em seu percurso criador, intensifica o trabalho, posto desafiar uma profunda reflexão acerca dos limites e da potencialidade do material com o qual opera. Este revela o seu código e assume estatuto de texto, ganha textura e espessura. Traduz-se. Como linguagem, toca o seu próprio ser em gradações pela emoção, pela percepção, pela lógica. Ao prescrutar as potencialidades e limites do suporte e do código com o qual opera, nova consciência de linguagem vai se revelando. Metalinguagem se fazendo.

Essa nova consciência de linguagem, os contínuos cotejos entre os códigos e em contínuas operações intersemióticas aguçam a visada metalinguística no próprio ato criativo. No dizer de Décio Pignatari (1974), são processos de metalinguagem analógica, 
internos ao ato criador, este estudioso explica que, desse modo, uma crise na lógica aristotélica é instaurada com a aparição de novas lógicas - lição que pode ser depreendida em mestres como Poe, Mallarmé, Pierce e Pound. Por contiguidade, em Rubião.

Em "Deus e o Diabo no Fausto de Goethe", Haroldo de Campos fala de "tradução como transfusão. De sangue. Com um dente de ironia poderíamos falar em vampirização, pensando agora no nutrimento do tradutor" (1981, p.208). Esse processo de vampirização sígnica, é nutriente importante quando se trabalha com linguagem.

A consciência de linguagem, esse vampirismo sígnico/artístico, que conferimos nos estudos de Picasso e na presentidade da cor, na obra de Miró, são "campo de indução - tal qual o de Retrato Oval de Edgar Alan Poe ou o nome refletido no espelho Bedlo/ Oldeb - sobre o qual se monta a primeira história de uma avatar", diz Pignatari (1974). Campo, no qual, Carroll constrói o poema em forma de rabo de rato, inserto em "Alice no País das Maravilhas", em que ocorre dupla iconização em planos simultâneos (verbal conto/rabo) e não verbal (Alice ouve a história olhando a cauda do camundongo) poema que assume configuração iconográfica.

O mestre de escrever aos recuos - Edgar Alan Poe - declara em seu trabalho sobre escrita cifrada que o leitor deve ter em em mente que toda arte da solução, no que respeita esses assuntos, deve ser encontrada nos princípios gerais da formação da própria linguagem.

Dono de profunda consciência de linguagem, atento à proposta metodológica de Poe, Machado de Assis explorou também a potencialidade do meio de que se utilizava, como tipógrafo, 
jornalista e escritor. O autor de "Memórias póstumas de Brás Cubas" retualiza em metalinguagem, nesta obra, um caligrama onde a ambiguidade exibe conotações de caráter fálico. Este encontrará correlações ideográficas com a parte (capítulo XXVI) em que se anuncia a vinda de Virgília. Tal labor com a linguagem encontra expressiva singularidade no $\boldsymbol{V}$ (de Virgília) - "um rabisco sem intenção alfabética" - e com conotações eróticas.

Nos interstícios da palavra - falada e escrita - Mallarmé lança os dados. "Un coup de dés" - poema que começa com ele próprio. O poema lança luz à página branca do papel, que acolhe a massa tipográfica - um caligrama polissêmico. O movimento de ondas do mar, de corpo no ato do coito, de contrações, sinfonia e letras engendram uma epopéia cujo herói seria um espermatozoide.

Estes artistas demonstram, em direção oposta à representação constituída, um esforço empreendido no sentido de tangenciar um espaço em que a primeiridade sígnica torna-se proeminente o espaço da potência criativa. Este encaminhamento nos remete novamente a Lewis Carroll, e desta feita, à imagem de Alice no lago, frente ao espelho da própria imagem. No olho do espelho d'água que inscreve o sensível, o fantasma indica o lugar negativo no antes (do mito), um ritual de passagem de Alice que, por razão, chora à beira do lago das lágrimas. (PALO, 2017).

No paradoxo do estranho, o mito transforma-se em literatura, ganha manifestações individuais do imaginário, dá morada ao insólito. Essa morada do insólito pode ser definida como o lugar da estética - posto ser também o lugar de uma fratura entre o sistema semiótico e o discurso (AGAMBEN, 2009). O lugar topológico em 
que o símbolo (terceiro) vampirizado, degenerado, destece a solidez dos significados em se que assentou/assenta socialmente o simbólico, por conseguinte, ícones presentam imagens fugidias, lembranças esparsas do que foram. Um campo de indução no qual se movimentam as possibilidades do devir (imagens, diagramas ou metáforas). Jamais tocam o objeto. De qualquer forma, apesar do penoso trabalho, todos esses artistas, no percurso criador, se visam à morada primordial, atestam a inexorável intangilibilidade que subjaz ao processo de criação.

É desse labor com a linguagem que emergem histórias em redação impecável, de linguagem concisa e sóbria, mas que contrastam com a forma obscura e insólita de seus arranjos, de "lógica inflexível" e "falando de coisas ilógicas." No território da arte, em que tudo é possível, labora Rubião com uma rede de acordos que resulta em penoso e intenso trabalho. Nele, autenticando o que se presume o inapreensível, o misterioso. Na experiência mesma da linguagem, torna-se ele próprio poeta. Correlato ao seu processo criador, seria seu encontro com o intangível. O fato é que o autor mineiro, tenazmente incorpora-o ao seu operar estético. Pela força mesma da palavra, pela plasticidade do verbo, pela sintaxe simples de insólitos arranjos pela gramatura ilógica. Murilo iconiza o intangível. Ao modo de Adão, nomeia-o: "Marina, a Intangível".

No "meu desamparo balbuciei oração para Marina, a Intangível" (RUBIÃO, 2016, p.111). Desde o título vão sendo indiciadas as pistas dessa proposição. Retomada no baralhamento de índices dispersos do mito bíblico, de figurações do poema de 
Edgar Alan Paul25, de descrições metalinguisticas de um processar o de José Ambrósio, no incessante esforço e árduo trabalho de composição do poema para Marina; ao que se agrega o encetar de grupos de ideias que emergem de reminiscências tumultuadas de uma época em que dogmas da vida religiosa afetariam o mundo, reverenciando-as parodicamente. Em sua brevidade, dentro do conto, de modo fragmentário, encontra-se tecida a complexidade de uma história, de uma mutação e de um destino. Das necessidades lógicas do espírito, a palavra descola-se da realidade circundante e converte-se em uma entidade nervosa.

O som e silêncio - ritmo puro - em regressões e progressões concorrem para que a linguagem verbal e o enigma que contém seja possível. O ritmo, como sabemos, situa-se no alvorecer de toda e qualquer linguagem, assim como no alvorecer da vida; nessa ordem de ideias, é ícone sonoro da criação.

A plasticidade das cenas faz figurar no cortejo: o andor, padres sardentos ladeados de mulheres grávidas, Marina e Maria da

25 No aproximar da figura desconhecida à janela, cuja descrição do rosto assemelhase à imagem de um corvo, "um nariz grosso e curvo". (RUBIÃO, 1999, p.80) - detalhe novamente retomado e que remete à primeira imagem do corvo no poema de Paul, vista através da janela e precedida de duas pancadas, dessas duas pancadas tais". (POE, 1986, p.902). Madrugada também ambienta o poema de Paul - a diferença está que no conto de Rubião são duas horas e no de poema meia noite. Se em Paul há uma ausência chorada, a de Eleonora, em Rubião, Marina é a presença ausente.-

Colocado na Bíblia grega, depois do Eclesiastes - mais especificamente na Vulgata, entre o Eclesiaste e a Sabedoria - este canto aparece na Bíblia hebraica entre os escritos que formam a terceira e a mais recente parte cânon judaico. Carrega consigo as discussões intermináveis sobre a época em que fora escrito, sobre a autoria e sobre o que sua história nos diz. O cântico tem mais o aspecto de coletânea de cantos próprios para esponsais, aparentemente unificados numa peça única. Estes cantos, produtos de mais de um autor anônimo, teriam sido burilados e reunidos em livro por um poeta, no pós-exílio, por volta do ano 400 a.C.. A tese de que o cântico foi escrito neste período helênico pode fundamentar-se no ato das tragédias desta cultura apresentarem o "coro", presente no texto. 
Conceição, santa e prostituta. Na esteira de Piglia, uma história visível esconde um relato secreto, "narrado de um modo elíptico" (2017, p.112) em cenas que se cruzam no diálogo entre o sagrado e o profano, entrecruzam-se hipóteses e rituais do cristianismo e ideias pagãs. Mescla poética. A plasticidade visual dos quadros na procissão, as várias linguagens que promovem o movimento da narrativa, as imagens por traz das palavras, tem-se vários textos cosendo - a aurora.

Sagrado e profano intercambiam valores e profundidade, cruzam-se e confundem-se. "Cântico dos Cânticos", é fonte de que é retirada a epígrafe, poema, de que um excerto é recuperado no corpo do texto muriliano, referindo-se exatamente à clave para a composição do poema dedicado à Marina, são colocados versículos utilizados por Machado de Assis. "A existência de Marina está neste trecho dos Cânticos: 'Eu vos conjuro, filhas de Jerusalém, que, se encontrardes o meu amado, lhe façais saber que estou enferma de amor." (RUBIÃO, 2016, p.115)

A ambiguidade comanda o jogo das ideias e do processo criador. "Os papéis jogados para o ar e espalhados pelo chão, atrapalharam-me. Quando me desvencilhei, encontrava-me só no terreiro e nenhum som". Análogo ao esforço de Mallarmé em dar uma explicação órfica do universo, 'o poema é irremediavelmente composto - apenas um lance ao acaso - feito de pétalas rasgadas e sons estúpidos (RUBIÃO, 2016, p.117). O lance para o antes faz o tempo mover-se ao futuro.

O mistério da criação se faz desde o princípio. Hipóteses de diferentes searas concorrem para explicá-la, das sementes do 
discurso mítico, do científico, do filosófico germinam registros. Encontramos na Bíbia a seguinte explicação para o fenômeno: "E a terra era sem forma e vazia, e havia trevas sobre a face do abismo; e o Esprírito de Deus se movia sobre a face das águas. E disse Deus: Haja luz e houve." (BíBLIA, Gênesis, 1:2,3). No princípio era o verbo.

Nessa ordem de ideias, antecede a palava de Deus: o silêncio, a escuridão, a indeterminação envolvendo o que esperava para ser criado. No livro da Gênesis, está escrito:

No princípio, criou Deus o céu e a terra. A terra era sem forma e vazia; e havia trevas sobre a face das águas. E disse Deus: Haja luz e houve. E Deus chamou à luz Dia; e às trevas Noite. E foi a tarde e a manhã, o dia primeiro. E disse Deus: Haja uma expansão no meio das águas, e haja separação entre águas e águas. (BÍBLIA, Gênesis, 1:1,6)

E Deus disse: "Façamos o homem à nossa imagem, conforme a nossa semelhança; E criou Deus o homem à imagem e semelhança de Deus" (BIBLIA, Gênesis, 1:26). No princípio era o verbo. O verbo fez o homem. (O verbo se fez homem). Essas palavras nos servem de orientação para pensar na intangilibidade dessa morada em que germina o processo da criação, já anunciado pelo mito bíblico. Morada primeira da indeterminação, do silêncio, da potência criativa à espera do verbo.

Em analogia, dizemos, esse é o trabalho que perfaz Murilo Rubião, na escritura de seu conto "Marina, a Intangivel".

Murilo é dono de profunda consciência de linguagem, leitor de Poe e entendedor de sua filosofia da composição. Ele executa com maestria as excêntricas lições metalinguísticas de Quixote, alimenta-se dos ensinamentos da Bíblia, e se diz fiel aprendiz do 
Cosme Velho com quem confessa: "aprendi os melhores truques do fantástico e mesmo do surrealismo". Seu projeto poético alinha-se com as metamorfoses que executa; repetições, releituras, rasuras e reescritas constantes são movimentos obrigatórios que vão propiciando ao artista a revelação - em cada lance - do novo signo que vai se instaurando. Como já observado, ocorre nesse processo uma subversão lógica que degenera o caráter simbólico em direção ao icônico.

Se Picasso atinge um espectro fantasmático de touridade para a composição do horror em Guernica, se Miró atinge a energia potente da cor, se, como presença e ausência sob a página, Mallarmé atravessa uma sucessão de ondas do acaso, e com um "riso sagrado" fecunda o espaço criador no lance de espermatozoides, Murilo em sua vampirização sígnica iconiza o intangível.

Já de início, no conto em questão, a intemporalidade, tão perseguida por Rubião, se faz pelo jogo temporal no lance para o antes do verbo: "antes que tivesse tempo de gritar por socorro". Antes da vida sentida e pensada - do ritmo que está ao alvorecer de toda e qualquer linguagem, inclusive, da vida. "Nem mesmo ouvia o bater do coração". Antes do verbo -" o silêncio me envolveu”. (RUBIÃO, 2016, p.110).

"Afastei de minha frente a Bíblia e me pus à espera de alguma coisa que me estava por acontecer. Certamente a vinda de Marina" (RUBIÃO, 2016, p.110). A temporalidade joga como passado e o devir. O registro sagrado é afastado e Marina estava por vir. A presença de Marina (presença pela ausência) adensa a complexidade das relações entre sagrado e profano. Marina figura-se em uma aparição, 
de modo a sugerir uma impressão festiva, através do vestuário e do porte cerimonial das pessoas que a acompanham; em andor, é seguida em procissão, a cena sugere cerimônia ritualística de um evento ligado ao sagrado. Mas a cena metonimicamente constrói a figura de uma mulher profana ${ }^{26}$ de lábios excessivamente pintados, olheiras artificiais muito negras, feitas a carvão, trajando roupas de cetim amarfanhado, com as barras sujas de lama e um chapéu de feltro, bastante usado, com um adorno de penas de galinha. A figuração de uma feiticeira, pelo menos, aquelas comparecem no imaginário da literatura para crianças. No entanto, através de um movimento análogo ao de uma câmera cinematográfica, tem-se a oscilação entre a pureza dos olhos e a concupiscência das coxas. Erotismo que endereça à figuração de uma prostituta. Impossível desfazer a ambiguidade, os anjos de metal prejudicam a visão de Marina por inteiro.

Marina é nome que tem origem no latim marinus - mar ou marinho - o que vem do mar. Não é difícil estabelecer uma analogia com as vênus de Boticelli e de Velazquez. A primeira surge no contexto de um imaginário cristão, cujas ideias vão residir na combinação do mundo antigo com o cristianismo, e que concebiam o amor na culminação da beleza. O poder do amor era encarnado na figura de Vénus, era o que relacionava o mundo dos homens com Deus, a beleza terrena era um reflexo da beleza superior. Vénus seria a divindade mais importante para os neoplatônicos. 0 que viria a motivar a pintura de Sandro Botticelli (1445 - 1510). 


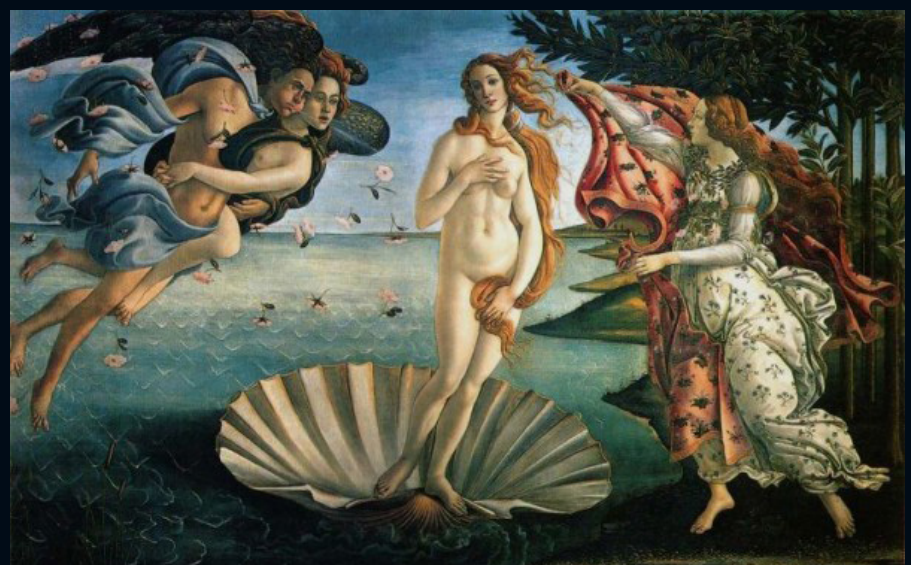

Figura 4. O nascimento de Vênus (1482) Sandro Botticelli. ${ }^{27}$

Esta pintura de Botticelli representa o nascimento da Vénus celeste gerida pela união do sangue da castração do deus Urano e a espuma do mar. A beleza. Arrastada pelos ventos, é recebida pela Hora da Primavera, que se aproxima para a acolher com um manto de flores. Em sua nudez luminosa, a deusa figurativizada por Botticelli, não sugere amor físico, mas simboliza o primado da verdade e da pureza, não seria propriamente Vênus que nasce no quadro de Botticelli, é a alma cristã que emerge das águas do Batismo. (HAUSER, 2003). Tal obra é paradigmática por comportar, não só a tensa relação entre a cultura pagã e a cristã, mas também a densa e complexa relação da arte com o inquietante contraditório coexistindo: à beleza e à pureza simbolizadas subjaz a face da intranquilidade do desejo, da morte, da violência, da crueldade ${ }^{28}$-convirá lembrar que o sexo de deus foi cortado, sangue e esperma, que caem ao mar, a geram. A fratura na representatividade

27 Sandro Botticelli (1484). O nascimento de Vênus, têmpera sobre tela, 172,5×278,5 cm. Galleria degli Uffizi, Florenza.

28 Didi-Huberman In: https://tamandua.tv.br/ 
instituída faz emergir a outra face. Na fissura, cifras disponibilizamse os artistas ao captá-la, trazem questionamentos ao discurso social que escamoteia a complexidade da experiência humana.

Na pintura de Diego Velázquez (1599-1660) Vénus ao espelho, o diálogo se faz dispondo Vénus em contexto notadamente humano. Mas o espelho faz aparecer o que estava oculto. O rosto se mostra e a figura antes fracionada é devolvida à plenitude de seu ser. "Rosto e quadris em miraculosa concordância configuram a mulher em atributos de deusa" (OLIVEIRA, 1999, p.95). Vénus é signo que recobre uma gama de interpretantes, confluem para ele: o mito, a deusa, a mulher, filiados ao paradigma do belo, do amor e do desejo. Velazquez mantém a tradição representacional do sagrado do mito, no entanto, interpõe nova interpretação. 0 espelho, nesta ordem de ideias, é móvel de uma nova semiose. Instaura a metáfora, na trama das relações mitológicas e no resgate das origens. Deusa do amor e geradora de Eros, o amor faz dele sua extensão, com ele se identifica e se confunde. Fusão de imagem especular. No imponderável cruzamento,vertigem. Vénus é Eros por sugestivo arranjo pictórico. Há uma ação translativa a metaforizar o amor e a beleza que se transformam em conceito. Uma qualidade entranhada no signo, o conceito, promove a iconização do símbolo.

Esta característica é notável no labor muriliano. A relação metafórica que ele constrói faz o símbolo degenerar-se em ícone e habitar o universo da primeiridade. Como o espelho que reflete refletido. Imagem de imagem, transgride a representação comum. 


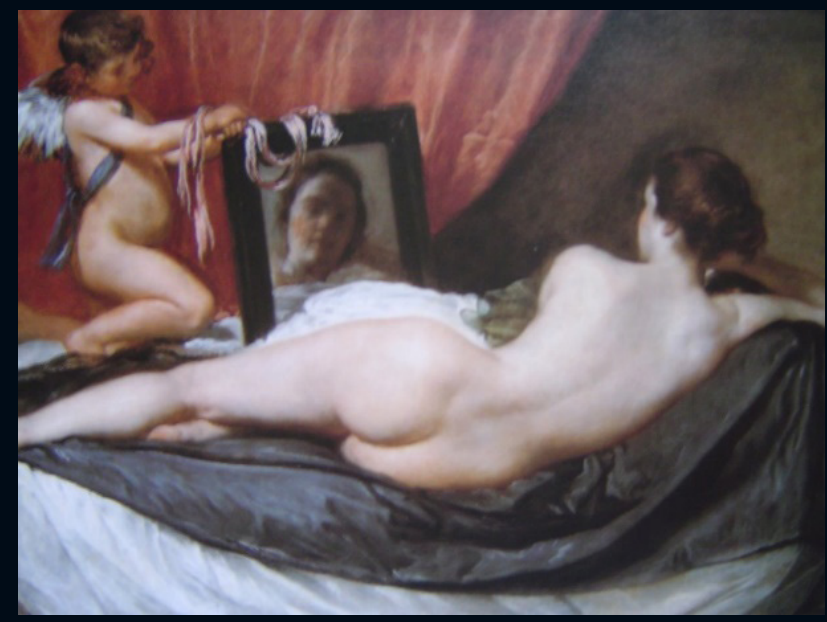

Figura 5. Venus ao espelho (1647-1651). ${ }^{29}$

Em Velazquez, a deusa, estendida sobre sua própria nudez, dá as costas ao olhar de quem a contempla. No centro, é o corpo que se oferece, como objeto de beleza. Se o rosto se volta para o olhar do espectador é por meio da uma imagem especular da deusa ou do imaginário de quem vê essa face. O rosto é parcialmente visível e se recolhe na insignificância de um plano secundário, na verdade. Destaca-se a fisicalidade, o erotismo e o vórtice das paixões. Velazquez conjuga beleza e sensualidade, no mesmo espaço, a imagem do rosto espelhada e os sinuosos quadris, se complementares, apontam para a deusa-mulher que por si só é uma metáfora. No plano da narrativa muriliana, pelas constantes fragmentações, pelo labirinto temporal, às relações de contiguidades, aos encadeamentos lineares e de causa e efeito entre as sequências dos acontecimentos, interpõem-se relações mais complexas, paralelísticas (simetrias, gradações, antíteses)

29 Diego Velázquez (1647-1651). Venus ao espelho, Óleo sobre tela. 1,22m x 1,77m, National Gallery, Londres. 
responsáveis por uma multiplicidade e simultaneidade de visões de um mesmo evento. As sequências mutuamente se remetem, como ocorre em Proust. Rarefaz-se a contiguidade do narrar, atingindo um nível qualitativo que se reveste de mera possibilidade de histórias. Esse movimento de degeneração sígnica, em vários níveis, desvela uma capacidade poética e um modo de tangenciar a multiplicidade da potência. Isso revela - a quem tem consciência da linguagem com que opera - a intangibilidade sígnica do primeiro. A primeiridade não pode ser tocada. É Intangível. Como Marina.

São vários os níveis em que Murilo Rubião labora para desfazer o instituído, ele profana o verbo e suas formas de organização e representação. Ao perfazer a profanação, promove a irrupção do insólito e do fantástico na fratura visual/verbal - língua / discurso - linguagem tomada como objeto de uma experiência da negatividade. Experiência que presentifica o originário da expressão e guarda em si: o mistério, o enigma, a intangibilidade. Esse presente se performatiza com a "infância da linguagem" e com o 'modo do não', na perspectiva colocada por Agamben.

A literatura muriliana, em intenso diálogo com muitos saberes, descria para criar, no potencial do estranhamento (Agamben, 2009). Em Murilo, a luta pela palavra a que o autor mineiro se refere não está relacionada à eficácia na transmissão de saberes - visíveis e legíveis - diferentemente, o contista atua com uma atenção flutuante, que o leva a uma suspensão intensa no momento de concluir e o faz estirar-se em várias dimensões entre o apreendido e o que o apreende, vivenciando uma tensão dialética - impensável ao positivismo - "que consiste em deixar-se desprender de seu saber sobre" (DIDI-HUBERMAN, 2017, p.23) e 
entregar-se à fenomenologia do conhecer em perpétua instância de transferência e projeção. O risco é grande. Mas é o mais belo risco da ficção. (2017, p.24)

\section{REFERÊNCIAS}

AGAMBEN, Giorgio (2018). Profanações. São Paulo: Boitempo editorial. (2014). Infância e História. B. Horizonte: UFMG. (2007). Estâncias. A palavra e o fantasma na cultura ocidental. B. Horizonte: UFMG.

(1993). A comunidade que vem. Lisboa: Editorial Presença.

ARGAN, Giulio (1993). Arte Moderna. São Paulo: Companhia das Letras.

BENJAMIN, Walter (2013). Escritos sobre mito e linguagem. São Paulo: Ed. Duas Cidades.

BLANCHOT, Maurice (2013). O livro por vir. São Paulo: Martins Fontes.

CALVINO, Italo. (1990). Seis propostas para o próximo milênio. São Paulo: Companhia das Letras.

CANDIDO, Antonio (1989). "A nova narrativa”. In: A Educação pela Noite e outros ensaios. São Paulo: Ática p.199- 206

CAMPOS, Haroldo (1981). Deus e o Diabo no Fausto de Goethe. São Paulo: Ed. Perspectiva.

CARVALHAL, Tania (1993). "A tradução Literária". In: Organon. Revista do Instituto de Letras da UFRGS. 7(20), 47-52

DIDI-HUBERMAN (2017). Diante da Imagem. São Paulo: Editora 34. FOUCAULT, Michel (1996). A ordem do discurso. São Paulo: Ed. Loyola.

GARCIA, Flavio (2016). "Estratégias narrativas dos novos discursos fantásticos, na contística de Murilo Rubião, como via de escape aos interditos dos duros anos da ditadura militar brasileira, em "Botão de Rosa", de O convidado (1974)". Literartes, 6, 26-45.

HAUSER, Arnold (2003). História Social da arte e da literatura. São Paulo: Editora Martins Fontes. 
IANNACE, Ricardo (2017). Murilo Rubião e as arquiteturas do fantástico. São Paulo: Edusp.

OLIVEIRA, Valdevino (1999). Poesia e Pintura: um diálogo em três dimensões. São Paulo: Editora da UNESP.

OSTROWER, Fayga (1995). Acasos e criação artística. Rio de Janeiro, Ed. Campus. PALO, Maria José (2017). "A potência criativa do insólito fantástico" In: Fantástico e seus arredores: figurações do insólito. CUNHA, Maria Zilda; Menna Ligia (Orgs). São Paulo: Ed. FFLCH/USP.

PICASSO, Pablo (1985). O pensamento vivo. São Paulo: Martin Claret Ed.

PIGLIA, Ricardo (2017). Formas breves, São Paulo: Cia das Letras.

PIGNATARI, DÉCIO (1974). Semiótica e Literatura. São Paulo: Ed. Perspectiva.

POE, Edgar Alan (1986). Eureka. São Paulo: Ed. Max Lomonad.

RANSDELL, Joseph. (1977) "Some leading ideas of Peirce's Semiottic" In: Semiotica 19, pp. 157-178.

SALLES, Cecília Almeida (1992). Crítica genética: uma introdução. São Paulo: Educ. (2009). Gesto inacabado - processo de criação artística. São Paulo: Annablume.

RUBIÃO, Murilo (2016). Obra Completa. Edição do centenário. São Paulo: Companhia das Letras.

SEGALL, Lasar (1984). "Escritos de Segall” In: V.D.'H BECCARI. O Modernismo Paulista. São Paulo: Brasiliense. 